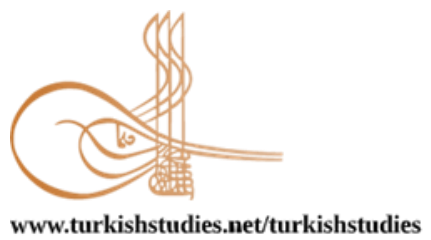

Turkish Studies

\title{
Doğal Ayıklanmacılık Yaklaşımına Göre Covid-19 Sürecinde Örgütlerin Değişimine Yönelik Bir Tartışma
}

\author{
A Discussion on the Change of Organizations During the Covid-19 Period According to the \\ Natural Selection Approach
}

\begin{abstract}
Ahmet İlhan*
Abstract: The Covid-19 outbreak, with its announcement as a pandemic, caused numerous changes in the social and economic fields, and these changes have become the new realities of our lives. Besides, the pandemic outbreak has begun to change the business practices for organizations and employees at a rapid pace in terms of the strategy, time, place, and sector variables. In this context, the principles of natural selection, which is an evolutionary approach based on biology, have been used especially to develop and expand the scope of organizational research and to explain organizational change and survival. This study aims to determine what changes the Covid-19 process has brought on organizations, along with the stages of crisis and change, and how organizations react to these changes within the framework of natural selection. Furthermore, in respect of the relationship between organizations and change during the Covid-19 outbreak, an attempt has been made to determine the types of organizational change that the organizations are subjected to due to environmental pressures in the context of the principles of the natural selection approach. In this context, it is possible to foresee the type of change that organizations are exposed to and their forward-looking positions as a result of the natural selection processes. In line with the information obtained from this research, it was determined that the form of the organizations started to change as a result of the new realities revealed by the crisis and changes during the Covid-19 outbreak and the conditions set by the pandemic. Accordingly, we can say that, during the Covid-19 outbreak, the organizations have gone through unplanned, macro, sudden, extended, proactive and reactive, active and passive, and revolutionary changes. As a result of these changes, according to the natural selection approach, some organizations diversify, cling, spread and win the fight for existence. On the other hand, if some organizations cannot adapt to change, diversify harmfully or uselessly or cannot provide resources, they lose their fight for survival and disappear.
\end{abstract}

Structured Abstract: Introduction: It was discovered that a case that was thought to have been observed first in the Wuhan city of the Public Republic of China in December 2019 and then spread over the world and which had not been seen before was infected by a new Coronavirus. As a result, an infectious type of Covid-19 has emerged and has been declared a "pandemic" by the World Health Organization (WHO) in line with the developments. The Covid-19 pandemic, which has influenced the whole world, has led to the emergence of an extraordinary period. This extraordinary period has initiated a global crisis. This crisis has affected every area of social life at different levels. It is anticipated that the degree of these impact levels will result in permanent and radical changes at the macro or micro levels, both individually and organizationally, in the near and distant future. The perspective of changes that emerge in extraordinary periods, especially in the limited conditions

\footnotetext{
${ }^{*}$ Dr. Öğr. Üyesi, Bayburt Üniversitesi, Sağlık Bilimleri Fakültesi, Sağlık Yönetimi Bölümü Asst. Prof., Bayburt University, Faculty of Health Sciences, Department of Health Management ORCID 0000-0003-2857-800X

ahmetilhandr@gmail.com

Cite as/ Atıf: İlhan, A. (2020). Doğal ayıklanmacılık yaklaşımına göre Covid-19 sürecinde örgütlerin değişimine yönelik bir tartışma. Turkish Studies, 15(6), 539-558. https://dx.doi.org/10.7827/TurkishStudies.44452

Received/Geliș: 23 June/Haziran 2020

Accepted/Kabul: 15 October/Ekim 2020

Copyright $\mathbb{C}$ MDE, Turkey
} 
that come with radical changes, highlights the approaches that determine the structure, properties, function and future prospects of organizational forms. There are several possible changes that the Covid-19 outbreak will cause on the existence, functioning and structure of organizations. Since the process started, organizations' and employees' ways of doing business and their culture have started to change. Organizations have to respond to the new situation by adapting to environmental pressures, also known as the new conditions. With the Covid19 outbreak, organizations are entering the natural selection process with new situational (conditional) pressures that are changing and becoming more normal on a global and national scale. In this context, organizations' assets have started to be compromised and the way they do business has started to differ. Therefore, it seems that the transition towards an order in which the organizations are in less physical reality has emerged. In this article, the changes caused by the Covid-19 outbreak in the organizations and the reactions of the organizations against the natural selection process were examined. In this study, the process of natural selection, which guided the understanding of the organizations, was explained first. Later, the Covid-19 outbreak was categorized as crisis and change stages, the initial emergence and the post-emergence, and tried to be examined. However, during the Covid-19 pandemic, the relationship between the change and the organization was handled in the plane of organizational change types. Finally, in the discussion section, the effects of the change brought about by Covid-19 were evaluated in terms of both individuals and organizations. With the conclusion and suggestions part, the change-related effects of the Covid-19 outbreak on organizations and future predictions were determined and expressed in a conceptual plane.

\section{Theoretical Framework}

The emergence of an ecological perspective that produces new insights into organizational change and adaptation has brought up a few discussions that are important for the field of organizational science. The first of these discussions focuses on environmental determinism and the question of strategic choice. Another discussion is related to the relative importance of selection and adaptation in explaining organizational change and survival. Such discussions are sometimes interpreted as reflecting the basic contrast between ecology and strategy ideas (Burgelman, 1991: 239). In this study, the natural selection approach, which is an evolutionary approach based on biology, was used to explain organizational change and survival. The components of the theory of evolution are included in the biological theory presented in the form of natural selection. The basic aspects of the theory in question are expressed in four basic principles. It is possible to say that these principles apply equally to the understanding and analysis of the organizations. Therefore, the principles of the natural selection approach are guiding the understanding of the organizations (McKelvey and Aldrich, 1983: 113-114). The theory of evolution, which comes from biology, is the dominant scientific theory among the general classification theories of organizations and is used for assistance in the classification of groups and the evolutionary typology of organizations (McKelvey, 1978: 1430). In this context, the basic principles of the natural selection approach are as follows: (1) Diversity, (2) The principle of natural selection, (3) The principles of enduring and spreading, (4) The fight for existence (McKelvey and Aldrich, 1983: 114-115). In order to better analyze the pandemic, in this study, the Covid-19 outbreak was examined in two parts as crisis and change. The crisis phase is a process that starts from the moment the virus is detected, an uncertain and new situation is faced, and measures are taken and implemented. The troubles experienced during the pandemic constitute the crisis stage and include the new developments arising from the uncertainties which are applied to all the areas of social life and which initiate the period of getting used to them. The stage of change is the development of models suitable for the new global order by struggling to adapt to the new environmental conditions caused by the crisis stage produced by the pandemic. During the Covid-19 outbreak, the uncertainty that has occurred in the social and economic areas due to the pandemic, social isolation and the new rules taken together have necessitated a change. Organizational change was imperative as the Covid-19 outbreak offers ambiguous, oppressive and new normal business realities. In this respect, organizational change is the main vital tool of organizations in their journey of existence during the pandemic of Covid-19. Accordingly, organizational change is a useful process that helps to optimize the performance of an organization and contributes to the organization's operation in the desired ideal situation (Chen, Suen, Lin, and Shieh, 2001: 2).

\section{Purpose}

This study aims to determine what changes the COVID-19 process has brought on organizations, along with the stages of crisis and change, and how organizations react to these changes within the framework of natural selection. In this context, the principles of natural selection, which is an evolutionary approach based on biology, have been used especially to develop and expand the scope of organizational research and to explain 
organizational change and survival. Furthermore, in respect of the relationship between organizations and change during the COVID-19 outbreak, an attempt has been made to determine the types of organizational change that the organizations are subjected to due to environmental pressures in the context of the principles of the natural selection approach. In this context, it has been tried to foresee the type of change that organizations are exposed to and their forward-looking positions as a result of the natural selection processes.

\section{Findings and Discussion}

The Covid-19 outbreak has profoundly and radically affected the way business and social life work together. Especially in the business world, the working practices of organizations and employees have begun to change. In fact, this change has a dominant aspect that determines the vital assets and futures of organizations. It is possible to identify and evaluate the status of organizations during the Covid-19 pandemic. Outputs of the effect levels of Covid-19 on organizations can be summarized as follows: (1) Status of the workforce, (2) Remote working system and management, (3) Increased need for technological products and systems and (4) Return of new living conditions: Virtual Reality. It would be misleading to see the effects of the pandemic only as a problem in the field of health. The outbreak has gone far beyond its scope, producing striking and permanent results for social and business life. The conditional features of the pandemic have made it necessary for organizations to change as a whole within the framework of new realities with the measures taken. This phase of change involves organizations doing business, developing different strategies and practical techniques, and experiencing a holistic change. In this context, it is possible to say that these changes expose organizations to a macro-level change. The change phase of the Covid-19 process has exposed organizations to experiencing different types of organizational change at various levels. Accordingly, Covid-19 determines the relationship between the organizations and the change according to the conditions it insists upon with different types of organizational change. Therefore, it can be envisaged that organizations will respond to this pressure with a revolutionary change strategy where everything changes in a holistic manner and a radical change is experienced throughout the organization by developing new methods at the organizational level, and by setting new designs and goals.

\section{Conclusion}

Within the framework of the information obtained in this research, there are benefits of the pandemic process and new realities it has brought into our lives. The Covid-19 outbreak has specifically and closely influenced organizational research, the assets, practices and organizational relationships of organizations. In this framework, organizations have started to turn into organizations with virtual functionality rather than physical structures. In a sense, the level of influence of the Covid-19 pandemic on organizations has been high. Therefore, organizations have met virtual reality as a result of the new normal conditions that have come with the pandemic. The change effect of the outbreak is imposing a change in business practices for both organizations and employees at the organizational level and to develop different strategies for the future. As a result of this change, the degree and harmony of the organizations' response to the change will determine their vital existence. Therefore, as a result of the change, the organizations will adapt to the process and will continue to exist or will not be able to keep up with it and will disappear. The Covid-19 period has forced organizations to change as a result of environmental pressures along with crisis and change stages. This obligation causes selections that include all kinds of changes for organizations. Accordingly, it is possible to predict and evaluate the position of organizations in the context of natural selection during the Covid-19 outbreak. In this regard, the changes made by organizations in the context of natural selection occur in the form of diversification. Therefore, it is possible to say that organizations should respond to the changes caused by environmental pressures in the pandemic process, especially in a functional (purposeful) manner. In terms of diversification, organizations achieve different levels in reacting and achieving success. Within the framework of natural selection, which is the second principle of the natural selection approach according to the aforementioned levels, some of the organizations become successful and continue their lives, while the others are eliminated and disappear. During the Covid-19 outbreak, the organizations respond to the diversification path and ensure the future-oriented organizations to continue their lives with the principle of enduring and spreading. In this context, enduring and spreading are seen in the structures of organizations that are successful and can survive. For this reason, by enduring and spreading, organizations can ensure the continuity and spread of diversification, which enables them to continue their lives for the future. Finally, the principle of the fight for the existence of the natural selection approach determines the survival of these organizations according to the effect levels of the new mandatory conditions emerging during the Covid-19 pandemic. As a result of the new 
realities revealed by the crisis and change stages in the Covid-19 and the conditions imposed by the process, the organizational form has begun to change. In this context, it is possible to foresee the type of change that organizations are exposed to and their forward-looking positions as a result of the natural selection processes. Accordingly, we can say that, during the Covid-19 outbreak, the organizations have gone through unplanned, macro, sudden, extended, proactive and reactive, active and passive, and revolutionary changes. As a result of these changes, the survival status of the organizations is determined in the context of the natural selection approach. If the organizations realize these types of change, they diversify, endure, spread and win the fight for existence according to the natural selection approach; if they cannot adapt to change, diversify harmfully or uselessly or cannot provide resources, then they lose their fight for survival and disappear.

Keywords: Organization, Natural Selection Approach, Covid-19, Change, Organizational Change

Öz: Covid-19 süreci, pandemi ilan edilmesiyle birlikte sosyal ve ekonomik alanda birçok değişimin yaşanmasına ve bu değişimlerin hayatımızın yeni gerçeklikleri olmasına yol açmıştır. Bununla birlikte pandemi süreci örgütler ve işgörenler açısından iş yapma pratiklerini strateji, zaman, mekân ve sektör değişkenleri açısından büyük bir hızla değiştirmeye başlamıştır. Bu kapsamda özellikle örgütsel araştırmaları geliştirmek ve kapsamını artırmak, örgütsel değiişim ve hayatta kalmayı açıklamak için biyoloji temelli evrimsel bir yaklaşım olan doğal ayıklanmacılık (seçilim) ilkeleri kullanılmıştır. Bu çalışma, Covid-19 sürecinin kriz ve değişim aşamalarıyla birlikte örgütler üzerinde meydana getirdiği değişimlerin neler olduğunu ve bu değişimlere karşı örgütlerin doğal ayıklanma çerçevesinde nasıl reaksiyon gösterdiğini tespit etmeyi amaçlamaktadır. Ayrıca Covid-19 sürecinde örgüt ve değiişim ilişkisi kapsamında örgütlerin çevresel baskılara karşı hangi örgütsel değişim türlerine maruz kaldığı doğal ayıklanma yaklaşımı ilkeleri bağlamında belirlenmeye çalışılmıştır. Bu bağlamda örgütlerin maruz kaldıkları değişim türünü ve bunun sonucunda doğal ayıklanma süreçleri sonucundaki ileriye dönük konumlarını öngörmek mümkündür. Araştırmadan elde edilen bilgiler doğrultusunda, Covid-19 sürecinde kriz ve değişim aşamalarının ortaya çıkardığı yeni gerçeklikler ve sürecin baskıladığı koşullar sonucunda örgüt formunun değişmeye başladığı tespit edilmiştir. Buna göre covid19 sürecinde örgütlerin; plansız, makro, ani, zamana yayılmış, proaktif ve reaktif, aktif ve pasif ile devrim niteliğinde değişim gösterdiklerini söyleyebiliriz. Bu değişimlerin sonucunda bazı örgütler, doğal ayıklanmacılık yaklaşımına göre çeşitlenir, tutunur, yayılır ve var olma mücadelesini kazanır. Buna karşılık bazı örgütler ise değişime uyum sağlayamaz, zararlı veya faydasız çeşitlenir ya da kaynak teminini sağlayamamasından dolayı ayıklanıp yaşam mücadelesini kaybeder ve yok olur.

Anahtar Kelimeler: Örgüt, Doğal Ayıklanmacılık Yaklaşımı, Covid-19, Değişim, Örgütsel Değişim

\section{Giriş}

İlk olarak Aralık 2019 tarihinde Çin Halk Cumhuriyeti'nin Hubei eyaletine bağglı 11 milyon nüfuslu Wuhan şehrinde görüldüğü ve oradan tüm dünyaya yayıldı̆̆ı, daha önce hiç görülmediği bildirilen bir olgunun yeni bir Coronavirüs ile enfekte olduğu saptanmıştır. Bu virüsün de SARS$\mathrm{CoV}$ ve MERS-CoV gibi bir zoonotik enfeksiyon yani hayvanlardan insanlara bulaştığı düşünülmektedir (TÜBA, 2020: 26). Bunun sonucunda Covid-19 bulaşıcı bir hastalık türü ortaya çıkmış ve Dünya Sağlık Örgütü tarafından "pandemi”" ilan edilmiştir. Pandemiler çoğunlukla insaninsan enfeksiyonunun yayılmasının bir sonucu olarak yaygınlaşan hastalık salgınlarıdır. Bugüne kadar tarihte birçok önemli bulaşıcı hastalık salgını ve pandemi görülmüştür. Pandemi genel olarak krizler, ulusal ve küresel toplulukların sağlık, ekonomi, toplum ve ulusal güvenliği üzerinde olumsuz etkilerle ilişkilendirilmiştir. Ayrıca, önemli derecede siyasi, ekonomik ve sosyal yapıda bozulmalara neden oldukları görülmüştür (Qiu, Rutherford, Mao ve Chu, 2017: 3). Pandemi dönemlerinde ortaya çıkan değişimler ve bunların sosyal yaşam üzerindeki etkileri araştırmacıların dikkatini çekmektedir. Tüm dünyayı etkisi altına alan Covid-19 salgını olağanüstü bir sürecin ortaya çıkmasına neden olmuştur. Birleşmiş Milletler Ticaret ve Kalkınma Konferansı (UNCTAD), Covid-19'un 2020'de küresel ekonomiye maliyetinin en az 2 trilyon dolar civarında olacağını açıklamıştır (Açıkgöz ve Günay, 2020: 521). Birçok ülke, vatandaşlarını bu hastalıklara karşı korumak amacıyla önemli miktarlarda bütçe ayırmaktadır. Bu bakımdan salgının ortaya çıktığı veya yayıldığı ülkelerde sürece 
bağlı olarak finansal sıkıntılar yaşanması mümkündür (Bostan, Erdem, Öztürk, Kılıç ve Yılmaz, 2020: 2). Bu bağlamda söz konusu bu olağanüstü dönem, küresel ölçekte bir kriz sürecini başlatmıştır. Yaşanan bu kriz süreci sosyal yaşamın her alanını değişik düzeylerde etkilemiştir. Özellikle bu etki düzeylerinin derecesinin, hem bireysel hem de örgütsel açıdan yakın ve uzak gelecekte makro ya da mikro düzeyde kalıcı ve köklü değişimlere neden olacağı öngörülmektedir. Dolayısıyla Covid-19 ve geçmişte yaşanan farklı salgınların ekonomik ve toplumsal düzeyde etkileri karşılaştırıldığında, örgütler ve işgörenler üzerindeki değişim etkisini kontrol altına almak için ekonomik ve yönetimsel kapsamda müdahalelerin önemi artmaktadır (Bingül Ak, Türk ve Ak, 2020: 195).

Örgütsel araştırmalarda bulguların geçerli olduğu koşullarla ilgili değişkenler, örgüt biliminin epistemolojik açıdan daha geniş bir şekilde uygulanabileceğini önermektedir. Dönemsel olarak değişen koşullar, örgütler hakkında yapılan genellemelerin değişmesine neden olmaktadır. Özellikle köklü değişimlerin yaşandığı sınırlı koşulların oluştuğu olağanüstü dönemlerde ortaya çıkan değişimler perspektifi, örgütsel formların yapısını, özelliklerini, işlevini ve geleceğe yönelik beklentilerini belirleyen yaklaşımları öne çıkarmaktadır. Söz konusu olağanüstü dönemlerde koşulların özellikleri gözden geçirilir ve örgütsel formların öngörülebilir düzeyde sınıflandırılması için bir taslak geliştirilebilir. Daha sonra, örgütsel düzeyde uygulanacak eylem araştırmalarını geliştirmek için perspektifin nasıl kullanılacağına dair yaklaşımlar belirlenebilir.

Covid-19 salgınının örgütlerin varlığı, işleyişi ve yapısı üzerinde yol açacağı çeşitli olası değişiklikler bulunmaktadır. Sürecin başladığı tarihten bu yana örgütler ve işgörenlerin iş yapma biçimleri ve kültürleri değişikliğe uğramaya başlamıştır. Söz konusu koşulların direttiği çevresel baskılara diğer bir adıyla yeni duruma örgütler değişerek cevap vermek zorundadırlar. Covid-19 salgınıyla birlikte örgütler küresel ve ulusal ölçekte değişen ve gittikçe normalleşen yeni durumsal (koşulsal) baskılarla birlikte doğal ayıklanma sürecine girmektedirler. Bu bağlamda örgütlerin varlıkları tehlikeye girmeye ve iş yapma biçimleri farklılaşmaya başlamıştır. Dolayısıyla örgütlerin daha az fiziksel gerçekliğin içinde oldukları bir düzene doğru geçişin ortaya çıktığı görülmektedir.

Örgütlerin yer aldıkları endüstri içinde daha az fiziksel etkileşim içinde oldukları ve uzaktan erişim modeli ile çalışma hayatına devam edilmesi düzenine doğru bir eğilim belirginleşmiştir. Aynı zamanda örgüt çalışanlarının, çalışmalarını fiziksel mekânın getirdiği sınırlamaların aşıldığı farklı bir iş yapma sisteminin şekillendiği dönüştürücü bir sanal yapı ortaya çıkmıştır (Müftüler Baç, 2020: 22-23). Bu bakımdan covid-19'un örgütler başta olmak üzere birçok farklı alanda önemli değişimlere neden olacağı şüphesizdir. Söz konusu bu değişimlerin derece ve kapsamı pandemi süresi ve tahribatı tarafından belirlenecektir. Bütün bunların sonucunda örgütsel düzeyde Covid-19 ile birlikte değişen yeni gerçekliklerin ortaya çıkması beklenmektedir (Hanioğlu, 2020: 24).

$\mathrm{Bu}$ makalede; Covid-19 sürecinin örgütler üzerinde meydana getirdiği değişimler, söz konusu değişimlere karşı örgütlerin doğal ayıklanma sürecinde verdikleri tepkiler ve Covid-19 sürecinde örgütlerin hangi örgütsel değişim türlerine maruz kaldıkları belirlenmeye çalışılmıştır. Buna göre çalışmanın ilk bölümünde örgütlerin anlaşılmasında yol gösterici olan doğal ayıklanma yaklaşımı süreci anlatılmaktadır. Daha sonra Covid-19 süreci, ilk ortaya çıkışı ve sonrası dönem olmak üzere kriz ve değişim aşamaları şeklinde bir sınıflandırmaya tabi tutularak incelenmeye çalışılmıştır. Bununla birlikte Covid-19 sürecinde değişim ve örgüt ilişkisi, örgütsel değişim türleri düzleminde ele alınmıştır. Tartışma kısmında ise Covid-19 sürecinin beraberinde getirdiği değişimin etkileri hem bireyler hem de örgütler açısından değerlendirilmiştir. Son olarak sonuç ve öneriler kısmıyla Covid-19 sürecinin örgütler üzerindeki değişim etkisi ve geleceğe yönelik öngörüler belirlenip kavramsal düzlemde ifade edilmeye çalışılmıştır.

\section{Doğal Ayıklanma (Seçilim) Yaklaşımı}

Örgütsel değişim ve adaptasyonda yeni anlayışlar üreten bir ekolojik perspektifin ortaya çıkması örgütsel bilim alanı için önemli olan birkaç tartışmayı gündeme taşımıştır. Bu tartışmalardan 
ilki, çevresel determinizm (belirlenimcilik) ve stratejik seçim meselesi etrafinda odaklanmaktadır. Diğer bir tartışma ise örgütsel değişim ve hayatta kalmayı açıklamada seçim ve adaptasyonun göreceli önemi ile ilgilidir. Bu tür tartışmalar bazen ekoloji ve strateji fikirleri arasındaki temel karşıtlığı yansıttığ1 şeklinde yorumlanmaktadır (Burgelman, 1991: 239). Bu çalışmada özellikle örgütsel değişim ve hayatta kalmayı açıklamak için kullanılan biyoloji temelli evrimsel bir yaklaşım olan doğal ayıklanma (seçilim) yaklaşımı üzerinde durulacaktır.

Örgütlerin evrimsel dinamikleriyle ilişkili olduğu düşünülen örgütsel sorunları aşmak için evrimsel ve sosyobiyolojik etkilerin kullanılması yol gösterici niteliktedir. Biyolojik ve kültürel evrimde, doğal ayıklanma teorisinin uygulanmasında temel olarak; (1) bireysel ve grup seçimine ya da daha genel olarak farklı örgüt düzeylerinde seçim çatışması olması ile (2) dolaylı seçim (seçim vekil değişkenine göre) konularına odaklanılmaktadır (Campbell, 1994: 23). Evrim teorisini bireyin kültürel yapısına uygulayan en önemli ve eski çalışmalardan birisi Campbell (1965)'in "Variation and Selective Retention in Sociocultural Systems" isimli çalışmasıdır. Bu çalışmada Campbell (1965) evrimsel ilkeleri, insan davranışının evrimi çalışmalarına uygulamaya çalışmıştır (Richerson ve Boyd, 2000: 257). Campbell (1994), evrim kuramının toplum bilimlerine yol gösterici bir metafor olacağını belirtmiş ve kuramsal olarak örgütsel nüfus içinde sosyokültürel evrimleşmeye katkıda bulunmuştur. Bu katkılar ise biyoloji ve toplum bilimleri arasında bir ilişkinin kurulması üzerinde etki yaratmıştır (Sargut, 2017: 23-24).

Campbell (1965), evrimsel ilkelerin uygulanması konusunda dört temel öneri sunmuştur. İlk olarak insanın sosyokültürel evrimi, evrimci teorinin yöntemlerini kullanarak incelenmelidir. Çünkü insan kültürü ve bununa birlikte gelişen örgüt kültürü, genler yoluyla üreme sırasında kişiden kişiye aktarılan bilgiler olduğu kadar, öğretim ve taklit yoluyla da kişiden kişiye aktarılan bilgilerdir. İkincisi, kültürel ve genetik evrim birbiriyle bağlantılıdır. Kültür genlerden farklıdır, çünkü insanlar genlerinin pasif alıcılarıdır ve kültür açısından ise aktif ajanlardır. Üçüncüsü, Campbell doğal ayıklanmanın (seçilimin) kültürel evrimde ana güç olarak kalmasını sağlar. Edinilen değişkenin miras yoluyla nasıl çalışacağını açıkça gösteren bir sistemdir. Doğal ayıklanma (seçilim), kültürün evrimini proksimal olarak yönlendiren kuralların nihai kaynağıdır. Dördüncüsü ise Campbell, doğal ayıklanmanın (seçilimin) doğrudan kültürel çeşitlilik üzerinde işlediğini savunmuştur. Dolaysıyla kültürel çeşitlilik seçimi, genetik çeşitlilik seçimi kadar nihai bir neden olarak görülmektedir (Richerson ve Boyd, 2000: 257-258).

Evrim teorilerinin bileşenleri doğal ayıklanma biçiminde sunulan biyolojik teorinin içinde yer almaktadır. Söz konusu teorinin temel yönleri dört temel ilke ile ifade edilir. Bu ilkelerin örgütlerin anlaşılması ve analiz edilmesi için aynı derecede uygulanabilir nitelikte geçerli olduğunu söylemek mümkündür. Dolayısıyla doğal ayıklanma yaklaşımının ilkeleri, örgütlerin anlaşılması noktasında yol gösterici niteliktedir (McKelvey ve Aldrich, 1983: 113-114). Örgütlerin genel sınıflandırma teorileri içinde biyolojiden gelen evrim teorisi, baskın bir bilimsel teori olup grupların sınıflandırılmasında ve evrimsel olarak örgütlerin tipolojilerinin belirlenmesi ve sınıflandırılmasında yardımcı nitelikte kullanılmaktadır (McKelvey, 1978: 1430). Bu bağlamda doğal ayıklanma yaklaşımın temel ilkeleri şunlardır (McKelvey ve Aldrich, 1983: 114-115);

\section{1. Çeşitlilik İlkesi}

Doğal ayıklanma süreci çeşitlenmelerle başlar. Her türlü değişim bir çeşitlenmedir. Bunlar; işlevli (amaçl1) veya kör çeşitlenme biçiminde olabilir. İşlevli (amaçl1) çeşitlenmeler, çevresel baskılar sonucunda adaptasyon seçimine neden olduğunda kasıtlı bir tepki olarak ortaya çıar. Kör çeşitlenmeler ise çevresel veya seçim baskılarından bağımsız olarak kaza veya tesadüfen meydana gelir. Yöneticiler ve yönetim teorisyenlerinin örgütsel kontrol konusuna tüm dikkatlerini vermeleri çeşitlenmelerin meydana geldiğine dair dolaylı bir kanıttır. Bu konuda; Corning (1974), örgütler içindeki çeşitlenmelerin işlevli olduğunu; Campbell (1969), Aldrich (1979) ve Weick (1979) kör 
olduğuna ve McKelvey (1982) ise belki de yüzde doksanının kör olduğunu ileri sürmüşlerdir (McKelvey and Aldrich, 1983: 114).

\subsection{Doğal Ayıklanmacılık İlkesi}

Örgütlerdeki bazı çeșitlenmeler, çevreden kaynak elde etmede diğerlerinden daha başarılıdır. Bu çeşitlenmeler, bir örgütün veya alt biriminin hayatta kalmasına katkıda bulunur. Buna karş1lık yararsız veya zararlı çeşitlenmeler, örgütlerin veya alt birimlerin daha az kaynağa sahip olmasına ve dolayısıyla hayatta kalma şanslarının daha düşük olmasına ya da ayıklanıp yok olmasına sebep olur. Aynı zamanda bu tür örgütler, zaman geçtikçe geri kalan örgütlerin faydalı çeşitlenmeleriyle karakterize edilmesi muhtemeldir. Ekolojik bir toplulukta, üye örgütleri diğer toplumlardan rekabete karşı kaynak elde etmede faydalı çeşitlenmeleri olan bir nüfusun hayatta kalma olasılığı artacaktır (McKelvey ve Aldrich, 1983: 114). Doğal ayıklanmacılık modeli, herhangi bir örgütün uyum sağlama yolunda ilerlemesinden ziyade, çok sayıda örgütün yapısında meydana gelen değişikliklerin seçici olarak yayılmasını içeren sonuçlara odaklanmaktadır. Bu bakımdan bazı çeşitlenmeleri diğerlerinden farklı olarak seçen veya belirli çeşitlenmeleri seçici olarak ortadan kaldıran tutarlı seçim kriterlerinin bir çalışması olarak değerlendirilebilir (Aldrich ve Pfeffer, 1976: 81-82).

\subsection{Tutunma ve Yayılma (Kalıtım) İlkesi}

Tutunma ve yayılma ilkesi, çalışanların nesiller boyunca faydalı çeşitlenmelerin korunmasını ve bir popülasyon boyunca bu çeşitlenmelerin yayılmasını açıklar. Biyolojik organizmaların aksine, örgütlerin yavruları yoktur, ancak bazı örgütlerin "bölünme" bakımından biyolojik organizmalara benzer olabileceği ileri sürülmüştür (McKelvey ve Aldrich, 1983: 114). Diğer bir ifadeyle tutunma ve yayılma ilkesi, nesiller boyunca faydalı çeşitlenmelerin soylarını sürdürebileceğini ifade etmektedir (Sargut, 2017: 24).

$\mathrm{Bu}$ aşamada, pozitif olarak seçilmiş çeşitlenmelerin seçici olarak tutulması için bir tutma mekanizmasının çalışması gerekmektedir. Tutma, belirli çeşitlenmeler korunduğunda veya çoğaltıldığında gerçekleşir. Organik evrimde tutma mekanizması, kromozom-gen sistemine dayalıdır. Buna göre, olumlu seçilmiş çeşitlenmeler hayatta kalır ve benzerlerini çoğaltır. Öğrenme süreci için bellek sistemi, gelecekte kullanılmak üzere pozitif olarak seçilen tepkilerin hatırlanabileceği araçlardır. (Aldrich ve Pfeffer, 1976: 81). Aslında sadece fiziksel olarak örgütlere odaklanmak olumlu genlerin tutulması hakkında net düşünmeyi engelleyebilir. Mayr (1969), burada metaforik olarak kullanırsak örgütleri, bir popülasyonun gen havuzunun bir kısmını tutan geçici damarlar olduğunu belirtmiştir. Bu noktada asıl önemli olan gen havuzunun korunmasıdır. Dolayısıyla, örgütsel bilim adamlarının üzerinde odaklandıkları önemli husus popülasyon havuzunun korunmasidır (McKelvey ve Aldrich, 1983: 114).

\subsection{Varoluş Mücadelesi İlkesi}

Yukarıda açıklanan ilk üç ilke, doğal ayıklanma sürecini açıklamaktadır. Ancak Lewontin (1978), Darwin (1859) tarafından belirtilen "yaşam mücadelesi" yaklaşımını temel alarak dördüncü bir ilkenin gerekli olduğunu ileri sürmüştür. Porter (1980)'ın, rekabet stratejisi alanında "endüstri yapısal gruplamaları" olarak adlandırdığı çalışması, popülasyon olarak ifade edilen ve benzetilen örgütlerle ilgilidir. Literatürdeki ilgili çalışmalar, örgütler arasındaki rekabet mücadelesine dair çok sayıda kanıt sunmaktadır (McKelvey ve Aldrich, 1983: 115).

Adaptasyon Darwin tarafından bir ilke olarak evrim teorisine dâhil edilmiştir. Bireyin diğer organizmalarla rekabet halinde ve çevresel stres karşısında hayatta kalmasını destekleyen çeşitlenmeler üreme başarısını artırma eğilimindedir. Bu nedenle korunma eğilimi diğer bir ifadeyle varoluş mücadelesi ilkesi ortaya çıkar. Darwin, Thomas Malthus'un "Nüfus Prensibi Üzerine Bir Deneme" den türettiği varoluş mücadelesinin, aynı kaynak için iki organizmanın kısa arzda gerçek rekabetinden daha fazlasını içerdiğini ifade etmiştir (Lewontin, 1978: 220). Dolayısıyla, bireyler ve 
örgütler arasındaki rekabet ile çevresel baskılar karşısında onların hayatta kalmasını destekleyen çeşitlenmeleri içeren varoluş mücadelesi ilkesinin gerekliliği ortaya çıkmaktadır. Bu bağlamda varoluş mücadelesi ilkesi, doğal ayıklanma yaklaşımının sağlıklı bir şekilde yürüyebilmesi için gerekli olan, bireyler ve örgütler arasındaki rekabet temelli ilişkinin temelini oluşturan önemli bir ilkedir (Sargut, 2017: 24).

Doğal ayıklanma yaklaşımında göz önünde bulundurulması gereken bir özellik daha dikkati çekmektedir. Bu konuda Weick'in (1979), örgütlerdeki insanların yasalaşmasının çeşitlenmeler olduğu fikrini temel alınabilir. Rekabet koşulları altında hayatta kalmaya elverişli çeşitlenmelerin seçilmesi nedeniyle belirli popülasyonların ve örgütlerin yapısı yıllar içinde şekillenmektedir. $\mathrm{Bu}$ görüşe göre çevresel ortamlar, etkili örgütlerin "hayatta kalma yollarını" belirler. Metaforik olarak çevresel kaynaklar, hayatta kalma yollarının bitişiğinde bulunur. Popülasyondaki örgütler etkili bir forma doğru ilerledikçe hayatta kalma yollarını artırırlar. Hayatta kalma yolları, genellikle ortamlardaki kaynakların ve rakiplerin karmaşık durumları içinde öngörülmeye çalışılır (McKelvey ve Aldrich, 1983: 115).

Weick (1979), çevrenin yeniden oluşturulması sürecinde evrimleşmenin öngördüğü ilkeler çerçevesinde; çeşitlenme, ayıklanma, tutunma ve yayılmayı içeren bir model sunmuştur (Sargut, 2017: 24). Çeşitlenme, belki de sosyo-kültürel ve biyolojik evrimi karakterize eden en belirgin özelliktir. Sosyokültürel düzeydeki farklılıklar, sosyal gruplar arasında, tek bir gruptaki üyeler arasında veya tek bir grubun hareket ettiği farklı durumlar arasında ortaya çıkabilir. Genel olarak, "çeşitlenmelerin sayısı ne kadar çok ve ne kadar büyük olursa, avantajlı bir inovasyon için firsatlar o kadar zengin olur" (Weick, 1969: 55-56). Dolayısıyla çeşitlenme ilkesi başta olmak üzere doğal ayıklanma ilkelerinin; örgütlerin ve bireylerin iş yapma biçimleri, gelişmeleri, hayatta kalmaları ya da yok olmaları hakkındaki konulara çözüm getirme noktasında destekleyici bir açıklama sağladığını söylemek mümkündür.

\section{Covid-19 Süreci}

Covid-19 süreci, yeni bir koronavirüsün neden olduğu salgın bir hastalığın dünya genelinde birçok farklı ülkeye yayılması sonucunda Dünya Sağlık Örgütü (WHO) tarafından pandemi ilan edilmesiyle başlamıştır. Pandemi döneminde Covid-19 süreci; teşhis ve tedavi yöntemlerini izleme, hastalığa karşı yeni tıbbi ürünler ve yöntemler geliştirme, uluslararası işbirliği ile ülkelerin güvenliğini sağlama, ekonomi, halkla ilişkiler ve sağlık yönetimi gibi farklı alanlarda bilimsel faaliyetlerin ve etkileşimin özenle yürütülmesi ve gerçekleştirilmesi gereken kritik bir süreçtir (TÜBA, 2020: 49). Pandemi ilan edilmesiyle birlikte bu süreçte salgını önlemeye yönelik olarak sosyal ve ekonomik olarak birçok tedbirler alınmaya ve uygulanmaya başlanmıştır.

Kapitalist sistem ve neoliberal politikalar çerçevesinde bu sürecin aşamalar halinde baştan bir değerlendirmesini yapmak yerinde olacaktır. Covid-19 süreci, aynı zamanda toplumun yaşam biçimini, sahiplenme tarzını, üretim tarzını ve doğal yaşam ile ilişkilerini radikal olarak değiştirmesinin gerekliliğini ortaya çıkardı. Bu konuda söz konusu değişiklikler, bireyin kendisini örgütlemesi ve popüler eylem değişiklikleri ile mümkün olabilecektir (Toussaint, 2020). Özellikle Covid-19 salgınının kapsamı ve etkisi genişledikçe sürecin özelliklerine bağlı olarak örgütlerin, örgütsel düzeyde farklı derecelerde yapılması gerekli uygulamaya dönük adımlar atması gerekecektir. Bu bakımdan herhangi bir örgüt için bu süreçte yapılması gereken kritik acil şart, riskleri ve olası senaryoları tanımlamak ve bunlara uygun eylemlerde bulunup değerlendirmektir. Örgütler burada varoluşsal olarak hayatta kalma riski ile karşı karşıyadır ve önümüzdeki sürecin belirsizliği sorunun önemine işaret etmekte ve ciddi adımların atılmasını gerekli kılmaktadır (KPMG, 2020: 1).

Koronavirüs, dünya ekonomisini her alanda güçlü derecede olumsuz bir şekilde etkileyerek geleceğe yönelik ipotek altına almaktadır. Uluslararası Çalışma Örgütü (ILO) hizmet sektörü başta olmak üzere; turizm, havacılık ve konaklama sektörleri gibi çeşitli alanlarda faaliyet gösteren farklı 
ölçekli tüm örgütlerin pandemi süreciyle birlikte ciddi zorluklarla karşı karşıya kaldığını belirtmiştir (Yavuz, 2020: 188). Ortaya çıkan bu durum, dünya iş ve ekonomisi için korkutucu bir seyir izlemektedir. Dünya ülkeleri genelinde, tüketici harcamaları herhangi bir ekonominin \% 70'ini desteklerken, Covid-19 süreci ile birlikte şimdi bireylerin ve toplulukların sosyal yaşamları, tüketim alışkanlıkları ve bunlara bağlı ticari faaliyetlerin tamamı olumsuz bir şekilde etkilenmekte ve zarar görmektedir. Bu süreçte; insanlar mağazalardan, restoranlardan, sinema salonlarından, ofislerden turizm noktalarından vb. diğer kamusal alanlardan kaçınmakta ya da sosyal izolasyon koşulları içinde mümkün olduğunca kısa bir süre için kalmaktadır. Bununla birlikte işgücü piyasasında; dünya çapında işten çıkarmaların başlaması birçok alanda durgunluk yaşanmasına sebep olmaktadır. Covid19 sürecinin tüm aşamalarıyla birlikte, küresel bir yavaşlamaya yol açması ve yeniden canlanmasının da 10 yıllık bir süreyi alabileceği öngörülmektedir (Barman, 2020: 2). Pandeminin sağlık, sosyal ve ekonomik etkileri doğrudan ya da dolaylı olarak yakın ve uzak gelecekte tüm dünyayı ciddi derecede tehdit etmektedir. Sürecin daha iyi analiz edilmesi için bu çalışmada, Covid-19 süreci kriz ve değişim aşamaları olmak üzere iki kısımda incelenmiştir.

Şekil1. Covid-19 Süreci Aşamaları

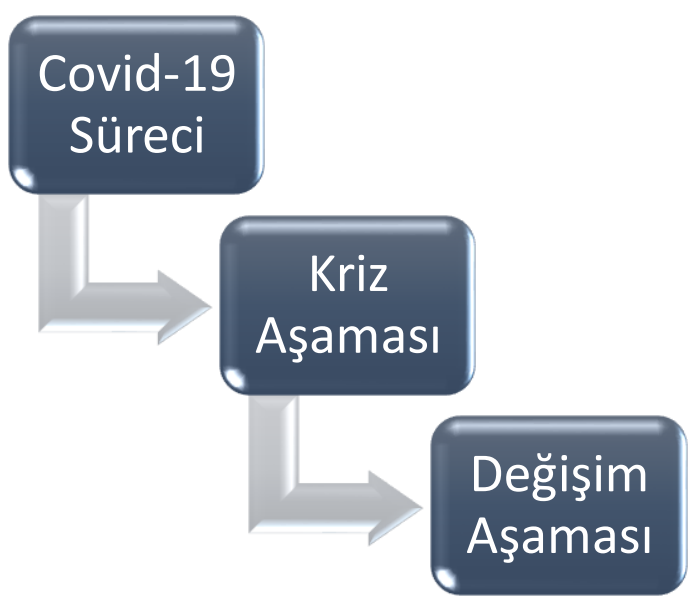

\subsection{Kriz Aşaması}

Kriz aşaması, virüsün tespit edildiği andan itibaren başlayan, belirsiz ve yeni bir durumla karşı karşıya olunan ve önlemlerin alınıp uygulandığı bir süreçtir. Bilinmezliklerin olduğu ve bunun sonucunda yaşanan yeni gelişmelerin sosyal yaşamın tüm alanlarına uygulanması ve buna alışılması için geçen süreçte yaşanan aksaklıklar kriz aşamasını oluşturmaktadır. Covid-19 süreci, beraberinde kriz aşamasının oluşmasına neden olmuştur. Kriz aşamasının gelişmesinde, örgütlerin çevreye uyum kabiliyetlerinin azalması ve başarısız olma ihtimallerinin artması gelmektedir. Diğer bir ifadeyle dış çevre koşullarının sürekli olarak değişmesi ve örgüt yönetiminin buna uyum sağlayamaması durumudur. Bu şekilde örgüt ve çevresi arasındaki mesafe artmakta ve bunun sonucunda kriz aşaması ortaya çıkmaktadır. Kriz; beklenilmeyen, rutin sistemi bozan, önemli değerleri tehlikeye atan, örgütlerin yaşamlarını tehdit eden ve kısa bir süre içinde hemen cevap verilmesi gereken bir durum olarak görülmektedir (Akdoğan ve Cingöz, 2009: 6). Koranavirüs pandemisinin bir kriz aşaması olduğu konusunda; uluslararası aktörler II. Dünya Savaşı'ndan sonra yaşanan “en büyük kriz” ve "büyük bir ekonomik felaket" tanımlarını yapmışlardır. Bu bağlamda covid-19, hem birey hem de örgütler açısından hayatın bir parçası haline gelmektedir. Covid-19 sürecinin kriz aşaması, sistem hatası ve çöküşe sebep olabilecek seviyede belirsizlikler içeren bireylerin ve örgütlerin birçok farklı alanda savaştığı bir durumdur (Kardaş, 2020: 46-47). Covid-19 sürecinin çalışma yaşamına olası etkileri kapsamında Uluslararası Çalışma Örgütü (ILO)' nün 18 Mart 2020 tarihli Bilgi Notu çalışmasında; Covid-19'un işgücü piyasaları üzerinde çalışma yaşamını üç temel boyutta etkileyeceği belirtilmiştir. Bu boyutlar; (1) İş sayısı (işsizlik ve eksik istihdam), (2) İş kalitesi 
(örneğin, ücretler, sosyal korumaya erişim), ve (3) Olumsuz işgücü piyasası sonuçlarına karşı daha savunmasız olan belirli gruplar üzerindeki etkiler şeklinde sıralanmaktadır. Bu noktada ILO, Covid19 sürecinin küresel işsizlik ve eksik istihdama etkisinin yüksek olacağını ve önemli bir artış göstereceğini öngörmektedir (ILO, 2020: 3). Covid-19 süreci, iş dünyası sürekli değişimlere uyum sağlama düzeyine gelene kadar kriz aşamasının devam edeceği bir süreç olup, etkisi küresel tedarik zincirlerini etkilemekte ve finansal piyasalar ile günlük işlerin işleyişini bozmaktadır. Covid-19 sürecinde kriz aşamasının iş (örgüt) ve birey (işgören) üzerinde çeşitli etkileri bulunmaktadır. Bu etkiler; farkındalık ve iletişim, işgücü mevcudiyeti, teknoloji ve sistem esnekliği, ticari planlar, kurul yönetişimi, işgücü yönetimi, küresel hareketlilik, sağlık ve refah ile insan yönetimidir (KPMG, 2020). Covid-19 süreci, sadece halk sağlığ alanında bir kriz değil, aynı zamanda küresel bir resesyonla birleştiğinde tüm dünya siyasetini ve gücünü değiştirme potansiyeline sahip olan bir krizdir. Covid-19 süreci kriz aşamasıyla birlikte, işgücü ve üretim pazarlarında örgütleri kapatmak ve işgörenleri evde kalmaya zorlamak veya büyük işten çıkarmalar gibi uygulamalar ön plana çıkmaktadır. Bu kriz süreci devam ettikçe, işsizlik oranı daha yüksek olacak ve tedarik zinciri bozulmaya devam edecektir. Bu kapsamda örgütlerin temel önceliği işgörenlerini korumak ve pandemi süreciyle birlikte ortaya çıkan yeni çevresel koşullara uyum sağlayarak dünyada iş faaliyetlerinin nasıl sürdürüleceği konusunda eylem planları geliştirip çeşitli stratejiler uygulamaları gerekmektedir (Açıkgöz ve Günay, 2020: 524-525).

Kriz dönemlerinde, örgütlerin genel olarak önceden bir eylem planına sahip olmaları söz konusu kriz döneminde çözüme yönelik süreçte daha hızlı eylemlerde bulunmalarını ve süreci mümkün olan en iyi şekilde yönetmelerini sağlamaktadır. Bununla birlikte kriz yönetim planı olan örgütler, Covid-19 gibi öngörülemeyecek düzeyde bir kriz durumunda süreci mümkün olan minimum zararla yönetebilmekte daha başarılı olacaklardır. Mevcut süreçte yapılan Koronovirüs Gündem Araştırması'na göre örgütlerin \%46'sının bir kriz planı olduğu belirtilmiştir. Ayrıca bu salgın sürecinde sosyal izolasyonun alınan en önemli tedbir olmasından dolayı bu kriz aşamasında birçok örgütün uzaktan çalışma modelini benimseyip uyguladığı ifade edilmiştir (Aydın Göktepe, 2020: 632). Covid-19 sürecinin beraberinde getirdiği kriz aşamasında; örgütlerin rasyonel ve çözüme yönelik bütüncül bir anlayış geliştirmeleri noktasında sürecin kapsamlı olarak analiz edilmesi gerekir. Buna göre, Covid-19 sürecinde kriz aşamasını oluşturan ve süreç içinde gözlemlenen bileşenler şunlardır. Üretim kapanışları, halk sağlığı gereksinimlerinin artması, mücbir sebep isteyen tedarikçiler, gecikmelere neden olan ek sınır kontrolleri, limanlar ve havaalanlarında tıkanıklık yaşanması ve Asya'dan Avrupa'ya yoğun deniz yolları iptal edilmesi, fiyat artışı ile Çin'den azalan çıkış kapasitesi, verimliliği ve kara taşımacılığını etkileyen işgücü sıkıntılarıdır (KPMG, 2020: 1).

Covid-19 sürecinde kriz aşaması, örgütlerin hayatta kalmalarını tehdit eden bazı bileşenler ortaya çıkarmaktadır. Örgütler açısından süreç içinde kriz aşamasında görülebilecek olan ve dikkat edilmesi gereken tehditleri şu şekilde sıralamak mümkündür. Söz konusu tehditler; uzun süreli daralma, iflaslar ve daha yüksek işsizlik oranı, yetersiz tedarik zinciri, petrol fiyatlarında oynaklık, tüketici harcamalarında ve iş yatırımlarında büyük düşüş, bankacılık krizi, büyük kamu açıkları, daha fazla seyahat kısıtlaması, daha fazla özel kısıtlama, gida enflasyonu, daha başarısız ülkeler ve ticaret politikalarıdır (Açıkgöz ve Günay, 2020: 525). Dolayısıyla örgütlerin hayatta kalmalarını sağlamak, sürdürülebilir yapılarını geliştirmek ve işgücünün korunması sağlamak için tehditlere karşı harekete geçilmesi gerekir. Bu kapsamda, örgütler ve çalışanlar arasında iş ve sosyal yaşam dengesi kurulmalıdır. Aynı zamanda kriz aşamasında yer alan tehditlere karşı müdahalede bulunarak hızlı bir iyileşme, uyum ve yönetişim anlayışı geliştirmek rasyonel bir eylem olacaktır.

\subsection{Değişim Aşaması}

Değişim aşaması, pandemi sürecinin ürettiği kriz aşamasının ortaya çıkardığı yeni çevresel koşullara uyum sağlama noktasında mücadele ederek yeni küresel düzene uygun modeller geliştirilmesidir. Diğer bir ifadeyle ortaya çıkan kriz aşamasından sonra alınan önlemler ve yeni 
normalleşme sürecine birçok alanda uyum sağlamak beraberinde değişim aşamasını gündeme getirmektedir. Kriz aşaması sonrası dönem, örgütsel ve sosyal yaşam alanlarında meydana gelecek olan taleplerin ve dönüşümlerin küresel yansımaları çerçevesinde evrilmesi sonucunda yeni modeller üreterek değişim aşamasını oluşturmaktadır. Ayrıca değişim aşaması, sürecin gerektirdiği yeni normalleşme özellikleriyle birlikte örgütlerin değişimi yönetebilmeleri açısından çeşitli firsatlar sunmaktadir.

Covid-19 süreci, sürecin özelliklerine bağlı olarak alınması gereken önlemler ve uygulamalar ile kriz aşamasını ortaya çıkarmıştır. Kriz aşamasından sonra ise belirli bir süre sonunda yeni koşullar ile firsatların geliştiği ve dönüşmeye başladığı bir süreç olan değişim aşamasına geçilmiştir. Artık bu aşamada, hem örgütler hem de bireyler açısından değişime ayak uydurulması gereken yeni iş modellerinin geliştirilmesi ve uygulanması gereken firsatların olduğu bir aşamaya geçilmiştir. Aslında değişim ile anlatılmak istenen genel olarak; yeni olasılıkların, firsatların ortaya çıktığı politika, davranış, yapı, yöntem, ürün, piyasa firsatı ve tasarım gibi çeşitli alanlarda yaşanan dönüşümleri içeren bir olgudur (D'ortenzio, 2012: 15). Pandemi salgınında artık süreç itibariyle değişim aşamasına geçilmiştir. Dolayısıyla bu aşamanın gerektirdiği koşullar çerçevesinde planlar geliştirilmeli ve uygulamaya yönelik yöntemler izlenerek faaliyetlerde bulunulmalıdır. Bu aşamada ele alınacak olan temel odak noktası, örgütsel düzeydeki değişim ile ilgilidir. Diğer bir ifadeyle Covid-19 sürecinin değişim aşamasında asıl anlatılmak istenen örgütsel değişimdir.

Değişim aşaması, mevcut iş yapma biçimleri ve uygulamalarının yakından etkilendiği farklı bir duruma geçişi temsil etmektedir. Bu süreçte işgörenler örgütlerdeki fiziksel mekândan bağımsız olarak işlerini sürdürmeye başlamışlardır. Yeni normal olarak tanımlanabilecek bir iş yapma pratiği ortaya çıkmıştır. Dijital destekli uzaktan çalışma biçiminin artmasıyla birlikte üretim ve hizmet sektörü gibi birçok farklı alanda otomasyon çabalarının arttığı görülmektedir. Bu durum sosyal anlamda büyük metropollerin üzerindeki nüfus ve ekonomi alanlarındaki ağırlı̆̆1 azaltması ve nispeten daha küçük yerlerin ilerleyen zamanlarda ön plana çıkmasına sebep olacağı beklenebilir (Zarifoğlu, 2020: 109). Özellikle alışveriş, eğitim, sağlık, bankacılık alanlarında faaliyet gösteren örgütlere ulaşımın internet altyapıları ile dijital platformda yapılması geleceğe yönelik teknolojik bir değişime gidildiğini göstermekte olup iş ve yaşam koşullarının bu kapsamda yeniden dizayn edileceğini işaret etmektedir (Güven, 2020: 252). Bu noktada dijitalleşmenin ekonomik, politik, sosyal, kültürel, askeri, diplomatik ve hukuki düzeyde çıktıları öne çıkmakta olup bireysel ve örgütsel bağlamda yaşamsal sonuçlar ortaya çıkarmaktadır (Şen ve Batı, 2020: 75). Aslında değişim süreci, örgütler ve işgörenler açısından varoluş ve iş yapma biçimleri noktasında fiziksel mekân ve çalışma pratiklerini değiştirmeye başlamıştır. Bu yüzden değişim aşaması sosyal yaşam alanı içindeki alışkanlıkları kökten değiştirerek yeni gerçekliklere geçişimizi hızlandırmaktadır.

Covid-19 süreci kriz aşamasında örgütlerin çok çeşitli yıkıcı düzeydeki gelişmelere hazırlık yapıp yanıt verdiği ve bunlardan kurtulmaya çalıştı̆̆ bir dönemdir. Değişim aşaması ise yeni gerçekliklerle birlikte ortaya çıkan çevresel koşullara cevap verilen ve iyileşmenin yaşanabileceği bir süreçtir. Değişim aşamasında genel olarak örgütlerin uygulayabilecekleri olası adımları şu şekilde sıralamak mümkündür. Diğer bir ifadeyle değişim aşaması örgütlerin; kriz aşaması sonrasında iş ortamının getirdiği zorlu koşullarla birlikte yeni iş modellerine ve iş yapma biçimlerine uyum sağlayıp bu doğrultuda çeşitlenme, tutunma ve yayılma stratejileri geliştirebilirlerse, o zaman yeni firsatlara sahip olabilecekleri ve hayatta kalmaya devam edebilecekleri bir süreçtir. Bu aşamada yaşanabilecek ve çözüme yönelik uygulanabilecek olan olası pratik adımlar şunlar olabilir (Little, 2020: 21-22).

(1) Yeni verimlilikler yaratmak, verimliliği artırmak ve "akıllı çalışma" uygulamalarını daha da genişletmek için çalışma ortamının sanallaştırılması deneyimine dayalı anlayış geliştirmek.

(2) Daha fazla otomasyon ve daha esnek çalışma biçimleri uygulamak. 
(3) Teşhis ve test gibi yeni uzak ürün ve hizmetler için potansiyeller de dâhil olmak üzere, müşterilerin çevrimiçi hizmetleri benimsemesindeki değişiklikleri adım adım uygulamak.

(4) Kriz sonrası dünyada değişim aşamasında çevikliği ve duyarlılığı artırmak için kriz sırasında kullanılan hızlı karar ve yetki verme deneyiminden yararlanmak.

(5) Kriz aşamasında ortaya çıkan durgunluk, yeni çevresel koşullar, belirsizlik ve konsolidasyondan kaynaklanan yeni birleşme ve satın alma fırsatlarını değerlendirilmesi.

(6) Krize karşı daha iyi hazırlık yapılması ve değişim aşamasında daha etkili iş sürekliliği ile risk yönetiminin uygulanması.

(7) Daha hızlı çözümler elde etmek için hızlı ekosistem yeniliğini desteklemeye yönelik yeni itici güç ve modeller uygulanması.

Covid-19 sürecinde değişim aşaması, örgütlere aynı zamanda çeşitli firsatlar vermektedir. Değişim aşaması, sürecin baskılayan koşullarına uyum sağlayabilen, yenilikçi, vizyoner ve esnek yapıdaki örgütlere hayatta kalabilmeleri ve gelişip ivme kazanabilmeleri için sürece özgü firsatlar sunmaktadır. Bu bağlamda değişim aşamasının pandemi sürecinin sona ermesi zamanına da bağlı olarak ortaya çıkan yeni normal süreçte örgütlere ileriye yönelik sunduğu olası firsatlar şu şekilde sıralanabilir. Bu firsatlar; daha fazla iş gücü koruması, yeni çalışma koşulları, yeni tedarik zinciri mekanizmaları, daha fazla online alışveriş ve daha fazla dijitalleşme, yeni ticaret mekanizmalarının ortaya çıkması, harcama alışkanlıklarında değişiklik, kârdan ziyade daha fazla hijyen ve güvenlik, karşılıklı yardım ve dayanışma sağlanması, çok taraflılık, temiz çevre konusunda toplumsal farkındalık, yeni ve akıllı teknolojiler, verimli ve uygun maliyetli toplantılardır (Açıkgöz ve Günay, 2020: 525).

\section{Covid-19 Sürecinde Örgüt ve Değişim İliş̧kisi}

Covid-19 sürecinde pandemi salgınıla birlikte sosyal ve ekonomik alanlarda meydana gelen belirsizlik durumu, sosyal izolasyon ve alınan yeni kurallar bütünü beraberinde bir değişimi zorunlu kılmıştır. $\mathrm{Bu}$ yüzden söz konusu değişimin örgütsel düzeyde ele alınması ve sürecin küresel özelliklerine bağlı olarak irdelenmesi uygun görülmüştür. Pandemi sürecinde ortaya çıkan değişimin çevresel boyutu diğer bir ifadeyle koşulların direttiği baskı önemlidir. Bu bakımdan örgütler sürekli değişen dinamik bir çevrede yer almalarından dolayı bu değişime eylemsel ve zihinsel olarak uyum sağlamalıdır (Çağlar, 2015: 9). Pandemi sürecinin yarattı̆̆1 koşulların, örgütler üzerindeki dönüşümsel etkisini incelemek ve bu etkinin derecesini, yönünü, şiddetini, yapısını belirlemek örgütlerin varoluşsal konumları için hayati bir durumdur. Bu bağlamda mevcut Covid-19 sürecinde artan oranda bir değişkenliğe sahip olan diş çevrede, sadece örgütsel düzeyde uyum yeteneği yüksek olan, esnek ve yenilikçi örgütler hayatta kalacaktır. Dolayısıyla bu süreçte örgüt yapısının değişimine duyulan ihtiyaç, örgütün planlı ve sürekli gelişim faaliyeti ile ilişkili bir sistemdir (Aycan, Kanungo ve Mendonça, 2016: 299-301).

Örgütsel düzeyde değişimin incelenmesinin gerekli olmasının nedeni örgütün karşılaştığ değişimin, arkasındaki güçler ya da baskılar tarafindan belirlenmiş olmasıdır. Bu kapsamda Covid19 sürecinde, örgütlerin değişimden etkilenmelerinin arkasında yer alan güçler; sosyal, politik ve makroekonomik güçler olarak gösterilmektedir (Suarez ve Olivia, 2005: 1018). Söz konusu güçler, bu süreçte örgütün yapısal özellikleri ve ortaya çıkan dinamik dönüşümlerle birlikte belirleyici olmaktadır. Bunun sonucunda örgütler, ya ayıklanıp yok olacak ya da başarılı olup yaşamını sürdürüp çeşitlenme becerisi gösterip tutunarak varlığını sürdürebileceği bir düzeye ulaşırlar. Bu bağlamda örgütlerin, içinde bulundukları Covid-19 sürecinin belirsiz, baskıcı ve yeni normal iş yapma gerçeklikleri sunması karşısında değişmeleri bir zorunluluk halini almaktadır. Dolayısıyla bu süreçte örgütsel bir değişim yaşanarak, sürecin getirdiği firsatları yakalamak ve çevresel koşullara uyum sağlamak mümkün bir hale gelebilir. Bu bakımdan örgütsel değişim, Covid-19 sürecinde örgütlerin varoluş yolculuklarındaki temel yaşamsal araçlarıdır. Buna göre örgütsel değişim, örgütün 
performansını optimize etmeye yardımcı olan ve örgütün istenilen ideal bir durumda çalışmasına katkıda bulunan faydalı bir süreçtir (Chen, Suen, Lin ve Shieh, 2001: 2). Bu bağlamda değişim ve örgüt ilişkisini Covid-19 sürecinde yaşanan dönüşümler çerçevesinde değerlendirebilmek için örgütlerde yaşanan değişimlerin türlerini incelemek yerinde olacaktır. Örgütsel değişim türleri, yaşanan sürece ve örgütün yapısına göre örgütlerde yaşanan değişimin kapsamı, niteliği, derecesi ve yapısı hakkında kategorik olarak bilgi vermektedir. Buna göre örgütsel değişim türleri; (1) Planlı değişim \& Plansız değişim, (2) Makro değişim \& Mikro değişim, (3) Ani değişim \& Zamana yayılmış değişim, (4) Proaktif değişim \& Reaktif değişim, (5) Aktif değişim \& Pasif değişim ve (6) Evrim niteliğinde değişim \& Devrim niteliğinde değişim şeklinde sıralanmaktadır (Koçel, 2018: 684; İlhan, 2018: 133; Zafar ve Naveed, 2014: 237-242; Serinkan ve Arat, 2013: 21-22, Basım, Şeşen ve Çetin, 2009: 21-22).

\subsection{Planlı Değişim \& Plansız Değişim}

Yönetim literatüründe genel olarak değişimden bahsedildiğinde akla ilk olarak planlı değişim gelir. Planlı değişim, değişim sürecinin her aşamasının önceden karşılaştırılıp değerlendirildiği ve uygulandığı bir değişim türüdür (Koçel, 2018: 687). Diğer bir ifadeyle eğer değişim, önceden ve istenerek belirli bir hazırlık sonucunda gerçekleştirilmiş ise planlı değişimden bahsetmek mümkündür (Çağlar, 2015: 21). Planlanan değişim; bir stratejik planın başarılı bir şekilde uygulanması, yeniden yapılanma planı veya bu büyüklükteki bir değişikliğin farklı bir şekilde uygulanmasıyla gerçekleşir (Tahilramani, 2011: 156). Buna karşılık plansız değişim ise örgütün aniden yaptığı ve daha önce üzerinde düşünmediği büyük çapta bir değişimi ifade eder (İlhan, 2018: 133). Bununla birlikte plansız değişim; örgütün üzerine gelen, hazırlıksız bir şekilde yakalandığı krize uymaktan ve kriz aşamasını başarılı bir şekilde atlatmak için daha önce düşünmediği önlemleri almak ve kararları uygulamaktan başka çaresi olmayan bir değişim türüdür (Koçel, 2018: 687). CEO aniden örgütten ayrıldığında, önemli halkla ilişkiler sorunları oluştuğunda, performans kaybı sonucunda hızlı bir şekilde müşteri kaybına veya diğer yıkıcı durumlara neden olduğunda plansız bir değişim meydana gelebilir (Tahilramani, 2011: 156).

\subsection{Makro Değişim \& Mikro Değişim}

Makro ve mikro düzeyde değişim, örgütte değişime konu olan alanların büyüklüğü ve sayısı ile ilgilidir. Makro değişim, örgütün tamamının bir bütün halinde değişime konu olmasını içermektedir (Basım, Şeşen ve Çetin, 2009: 22). Buna karşılık mikro değişim ise örgüt içinde alt ya da üst düzeyde herhangi bir konuyla ilgili yapılması gereken değişimi ifade eder (Serinkan ve Arat, 2013: 21). Makro değişim, örgütün bir bütün halinde diğer bir ifadeyle tamamının değişmesini içermektedir. Aynı zamanda bu değişim, örgüt geliştirme olarak da ifade edilmektedir. Makro değişimde geliştirilen farklı strateji ve teknikler, örgütün bir bütün halinde tamamının performansını yükseltmek için kullanılmaktadır (Koçel, 2018: 687). Buna karşılık, örneğin pazarlama departmanında satış kanalları ve teknik birimler arasında ortak çalışma yapılması ve elde edilen sonuçlara dayalı olarak geri bildirim ve düzenlemeler yapılması mikro düzeyde değişimi ifade etmektedir (İlhan, 2018: 134).

\subsection{Ani Değişim \& Zamana Yayılmış Değişim}

Ani ve zamana yayılmış değişim, yaşanan örgütsel değişimlerin gerçekleştirilme hızı diğer bir ifadeyle gerçekleştirilme süreleri ile ilgili değişim türleridir. Bu bağlamda, örgüt içinde bazen kısa bir sürede iç ve dış çevresel koşullara bağlı olarak değişim planlanarak hemen uygulamaya konulup arzu edilen noktaya ulaşmak hedeflenir. İşte bu tür değişimlere ani değişim adı verilir. Diğer yandan bazen de ortaya çıkan gelişmelere göre değişim belirli bir safhada, zaman aralığında süreye yayılarak adım adım aşamalı olarak gerçekleştirilmeye çalışılır. Bu tür değişimlere ise zamana yayılmış değişim adı verilmektedir (Basım, vd., 2009: 22; İlhan, 2018: 134). 


\subsection{Proaktif Değişim \& Reaktif Değişim}

Proaktif değişim, geleceğe yönelik olarak yapılan tahminler ile ilgili bir değişim türüdür. Buna göre, örgüt içinde yapılan bir değişimin proaktif olması, gelecekte olması beklenen çevre koşullarına göre öngörülerde bulunup değişiklik yapılmasını içermektedir (İlhan, 2018: 134). Tahmin edilen çevre koşullarına göre bir örgütün; iş ve faaliyet prosedürlerinin değiştirilmesi, teknolojik çalışmaların geliştirilmesi ve iş anlaşmalarının düzenlenmesi birer proaktif değişimdir (Koçel, 2018: 687; Zafar ve Naveed, 2014: 242). Reaktif değişim ise değişen çevre koşullarına göre örgütlerin karşılaştıkları bu yeni koşullara uyum sağlayabilmek için bir anlamda vermiş oldukları bir çeşit tepkidir (Koçel, 2018: 687).

\subsection{Aktif Değişim \& Pasif Değişim}

Aktif değişim, örgütün yapmış olduğu herhangi bir değişiklik sonucunda dış çevresini etkilemeyi başardığ durumda ortaya çıkan bir değişim türüdür. Örneğin, bir örgütün teknoloji geliştirerek kullanmaya başlaması hem kendi örgütsel yapısında hem de faaliyet gösterdiği endüstride çeşitli değişikliklere yol açabilir. Ortaya çıkan bu değişiklikler, aktif bir değişim olarak nitelendirilir (Çağlar, 2015: 22). Pasif değişim ise örgütün kendi iç yapısında değişiklik yaparak dış çevrede meydana gelen değişikliklere ve koşullara uyum sağlaması için gerekli olan bir değişim türüdür. Örneğin, bir örgütün teknolojik gelişmelere bağlı olarak ortaya çıkan değişimlere uyum sağlamaya çalışması pasif bir değişim olarak değerlendirilmektedir (Serinkan ve Arat, 2013: 22).

\subsection{Evrim Niteliğinde Değişim \& Devrim Niteliğinde Değişim}

Evrim niteliğinde değişim; aşamalı, artımsal ve dar kapsamlı olarak gerçekleşen bir değişim türüdür. Bununla birlikte evrim niteliğinde değişim, bir örgütün yapısının ve stratejisinin ortaya çıkan koşullara göre gerçekleşen değişikliklere uyum sağlamak için artımsal olarak geliştirilmesine, tasarlanmasına, düzenlenmesine ve uyarlanmasına yönelik bir değişim türüdür (Jones, 2017: 290). Söz konusu değişim türünde sürekli ve artımsal olarak geliştirilmeye çalışılan artan bir iyileştirme öngörüldügünden dolayı Japonların örgütlerinde uyguladıkları Kaizen yaklaşımı evrim niteliğinde değişime örnek olarak gösterilebilir (Basım, vd., 2009: 22). Buna karşılık devrim niteliğinde değişim ise hızlı, radikal ve örgütsel düzeyde geniş kapsamlı bir değişimdir. Devrim niteliğinde değişim, yeni ve hızlı yöntemler bulmak için girişimlerin yapıldı ğı, eylemlerin gerçekleştirilme biçimlerinde köklü farklılıkların, yeni yapının ve amaçların ortaya çıktığı ve örgütün tüm seviyelerinde ses getiren bir değişim türüdür (Jones, 2017: 291). Devrim niteliğinde değişimde, her şey birden tamamen değişime uğrayarak yeni baştan düzenlenerek sağlanmaya çalışılır. Bu bakımdan değişim mühendisliği, inovasyon ve yeniden yapılandırma devrim niteliğinde değişim türünün en önemli örnekleri olarak gösterilebilir (Çağlar, 2015: 22; Jones, 2017: 291).

\section{Tartışma}

Covid-19 süreci, salgınla birlikte iş ve sosyal yaşamın işleyiş biçimini derinden ve köklü bir şekilde etkilemiştir. Özellikle iş dünyasında, örgütlerin ve işgörenlerin çalışma pratikleri biçim değiştirmeye başlamıştır. Hatta bu değişim örgütlerin yaşamsal varlıklarını ve geleceklerini belirleyecek derecede baskın bir özelliğe sahiptir. Örgütlerin Covid-19 sürecindeki durumlarını tespit etmek ve değerlendirmek mümkündür. Bu çerçevede Covid-19 sürecinde örgütlerin hangi tür değişimlere maruz kaldığını ve bu değişimlerin sonucunda örgütlerin hayatlarını sürdürebilmelerinin doğal ayıklanmacılık yaklaşımına göre nasıl sonuçlanacağı öngörülebilir.

Covid-19 sürecinin örgütler üzerindeki etki düzeylerinin çıktıları; (1) İşgücünün durumu, (2) Uzaktan çalışma sistemi ve yönetimi, (3) Teknolojik ürünlere ve sistemlere olan ihtiyacın artması ve (4) Yeni yaşamsal koşulların getirisi: Sanal Gerçeklik şeklinde özetlenebilir. Bu çalışmanın amacını pandemi ilan edilmesiyle birlikte Covid-19 sürecinin örgütler üzerinde meydana getirdiği değişimler ve örgütlerin bu değişimlere karşı doğal ayıklanma sürecinde verdikleri tepkilerin incelenmesi oluşturmaktadır. Pandemi süreci ilk olarak tüm dünyayı etkisi altına alan küresel boyutta bir kriz 
aşaması haline gelmiş̧ir. Daha sonra süreç kriz aşamasından yeni normal gerçekliklerin çevresel koşullarla birlikte baskılaması sonucunda değişim aşamasına dönüşmüştür. Sürecin etkilerini sadece sağlık alanında yaşanan bir problem olarak görmek yanıltıcı olacaktır. Söz konusu süreç, kapsamının çok ötesine geçerek sosyal ve iş hayatına yönelik çarpıcı ve kalıcı olmaya eğilimli sonuçlar ortaya çıkarmışır.

Covid-19 sürecinin değişim aşaması, örgütleri çeşitli düzeylerde farklı örgütsel değişim türlerini yaşamalarına maruz bırakmıştır. Buna göre Covid-19 süreci, direttiği koşullara göre örgüt ve değişim ilişkisini örgütsel değişim türlerine göre belirlemektedir. Covid-19 süreci birden ortaya çıkan ve hayatımızın tüm pratiklerini alt üst eden bir süreçtir. Örgütler, bu sürece hazırlıksız, aniden ve beklemedikleri bir șekilde yakalanmışlardır. Söz konusu süreç belirsiz ve örgütleri etkileyen bir özelliğe sahiptir. Sürecin bu özellikleri örgütlerin plansız bir örgütsel değişim yaşamalarına sebep olmuştur. Bu şekilde örgütler sürecin ani ve belirsiz yapısına bağlı olarak plansız değişim yoluna gitmişlerdir. Böylece örgütler, aniden ve üzerinde düşünmediği büyük çapta bir değişim yaşamak zorunda kalmışlardır. Dolayısıyla örgütlerin üzerine gelen, hazırlıksız olarak yakalandığı süreçten başarılı bir şekilde çıkabilmek için daha önce hiç düşünmediği önlemleri almak ve kararları uygulamaktan başka çareleri kalmamıştır. Pandemi sürecinin koşulsal özellikleri, alınan tedbirlerle birlikte yeni gerçeklikler çerçevesinde örgütlerin bir bütün halinde değişmesini zorunlu kılmıştır. Söz konusu değişim aşaması, örgütlerin iş yapma biçimlerini, farklı stratejiler ve uygulamaya dönük teknikler geliştirmelerini ve bütünsel bir değişim yaşamalarını içermektedir. Bu bağlamda ortaya çıkan bu değişikliklerin, örgütleri makro düzeyde bir değişim yaşamaya maruz bıraktığını söylemek mümkündür. Covid-19 sürecinin değişim aşamasının getirdiği yeni çevresel koşullar ile salgının önlenmesine yönelik sosyal izolasyon önlemleri örgütlerin çeşitli sürelere bağlı olarak değişim evreleri yaşamalarına neden olmaktadır. Yeni gerçekliklerin ortaya çıkması örgütler üzerinde yaşanan değişimin getirdiği yeniliklerin gerçekleştirilme hızını belirlemektedir. Buna göre, yeni yaşamsal koşulların getirisine karşı örgütlerin verdikleri tepki ani ve zamana yayılmış olarak gerçekleştirilmektedir. Covid-19 sürecinde örgütler, bazı değişikliklere yaşamsal anlamda kısa sürede cevap vererek ani bir değişim gerçekleştirirler. Bazen de söz konusu değişikliklerin sürdürülebilirliği noktasında aşamalı olarak zamana yayılmış bir değişim yaşarlar. Dolayısıyla pandemi sürecinin değişim aşamasının çevresel baskıları, örgütleri hem ani hem de zamana yayılmış değişim yaşamaya yönlendirmektedir.

Diğer yandan Covid-19 sürecinin örgütler üzerindeki etki düzeyleri yaşamsal noktada; proaktif ve reaktif değişimler göstermektedir. İlk olarak Covid-19 sürecinin kriz aşaması, çevre koşullarını değiştirmiş ve geleceğe yönelik belirsiz bir ortam yaratmıştır. Söz konusu belirsizlik ise örgütlerin hazırlıksız olarak yakalandıkları bu sürece uyum sağlayabilme çabasıdır. Bu aşamada örgütlerin, belirsizliğin hâkim olduğu değişen çevre koşullarına uyum sağlamak için reaktif bir değişim gösterdiklerini söyleyebiliriz. İkinci olarak ise pandemi sürecinin değişim aşaması, örgütsel düzeyde yeni yaşamsal koşulları ve çalışma sistemlerini gündeme taşımaktadır. $\mathrm{Bu}$ noktada örgütlerin, yeni çevresel koşulların belirginleşmesiyle birlikte geleceğe yönelik öngörülerde bulunup varlığını sürdürebilmek ve performansını artırabilmek için proaktif bir değişim gösterme eğiliminde olduklarını söylemek mümkündür. Covid-19 sürecinde örgüt ve değişim ilişkisi, örgütsel düzeyde gerçekleştirilen değişimlerin etki derecelerini belirlemektedir. Pandemi sürecinin yeni yaşamsal zorunlulukları, örgütlerin kendi iç yapılarında yapmış oldukları değişimin gerekliliğini ve etki derecesini belirlemektedir. Bu bağlamda, Covid-19 sürecinin örgütlerin teknolojik ürünlere ve sistemlere olan ihtiyacını artırması yapısal olarak örgütlerin aktif bir değişim özelliği sergilemesine neden olabilmektedir. Aynı zamanda yeni sürecin getirileri örgütlerin faaliyet gösterdikleri endüstrideki çevre ve rekabet koşullarına uyum sağlamak için kendi örgüt bünyelerinde değişiklik yapmalarına neden olabilir. Dolayısıyla pandemi sürecinin değişim aşaması, örgütlerin kendi yapılarında bir değişim yaparak yeni koşulsal getirilere uyum sağlama noktasında pasif değişim davranışında bulunmalarını sağlayabilmektedir. 
Son olarak Covid-19 sürecinin değişim aşaması, örgütler üzerinde köklü değişikliklerin yapılmasına neden olacak uygulamalara yol açmaktadır. Özellikle süreçte uzaktan çalışma sistemi ve yönetimi şeklinde ortaya çıkan yeni yaşamsal koşullar, örgütsel düzeyde yöntemler geliştirilmesine olanak hazırlamaktadır. Örgütler, pandemi sürecinde çevresel koşullara bağlı olarak örgütün yapısını, stratejisini belirleyip bir sistem tasarlayıp geliştirerek evrim niteliğinde bir değişimi benimseyebilirler. Aynı zamanda pandemi sürecinin değişim aşaması, beraberinde ortaya çıkardığı zorunlu değiş̧kenlerle birlikte örgütleri köklü değiş̧iklikler yapmaları konusunda baskılamaktadır. Dolayısıyla örgütlerin söz konusu baskıya, örgütsel düzeyde yeni yöntemler geliştirerek, yeni tasarım ve amaçlar belirleyerek her şeyin bütünsel olarak değiştiği, örgüt genelinde köklü bir değişimin yaşandığı devrim niteliğinde bir değişim stratejisi ile cevap vermeleri öngörülebilir.

\section{Sonuç}

Covid-19 pandemisi, küresel olarak tüm dünyayı etkisi altına alan bir kriz sürecini başlatmıştır. Süreç zaman ilerledikçe alınan tedbirler ve hayata geçirilen uygulamalarla birlikte bir değişim sürecine dönüşmüştür. Bu dönüşümün getirdiği yeni normal yaşamsal koşullar, ekonomik ve sosyal yaşam alanlarının yeniden dizayn edilmesine yol açmıştır. Araştırma kapsamında elde edilen bilgiler çerçevesinde pandemi sürecinin getirileri ve hayatımıza kattığı yeni gerçeklikler bulunmaktadır. Özellikle Covid-19 süreci; örgüt araştırmalarını, örgütlerin varlıklarını, uygulamalarını ve örgütsel ilişkileri bütünsel düzeyde yakından etkilemiştir. Bu çerçevede örgütler, fiziksel bir yapıdan daha ziyade sanal işlerliğe sahip örgütlere dönüşmeye başlamıştır. Bir bakıma covid-19 sürecinin örgütler üzerindeki etki düzeylerinin derecesi yüksek olmuştur. Dolayısıyla örgütler pandemi süreciyle birlikte yeni normal koşulların getirisi sonucunda sanal gerçeklik ile tanışmışlardır. Sürecin değişim etkisi, örgütsel düzeyde hem örgütler hem de işgörenler açısından iş yapma pratiklerini değiştirmeye ve bu doğrultuda geleceğe yönelik farklı stratejiler geliştirmeye zorlamaktadır. $\mathrm{Bu}$ değişim sonucunda örgütlerin yaşamsal olarak varlıklarını değişime karşı gösterdikleri tepkinin derecesi ve uyumu belirleyecektir. Dolayısıyla değişim sonucunda örgütler, sürece uyumlanacak ve varlığını sürdürecek ya da ayak uyduramayıp ayıklanıp yok olacaktır.

Örgütlerin Covid-19 sürecinde ortaya çıkan yeni çevresel koşulların baskıladığı değişime bağlı olarak doğal ayıklanma yaklaşımına göre yaşamsal varlıkları belirlenecektir. Buna göre örgütler, doğal ayıklanma yaklaşımı sonucunda çevresel değişimlere verecekleri tepkinin derecesine göre çeşitli şekillerde; hayatta kalacaklar, gelişecekler ya da yok olacaklardır. Doğal ayıklanma yaklaşımı bağlamında örgütlerin konumu değişkenlik göstermektedir. Örgüt çalışmalarında temel alınarak kullanılan biyoloji temelli bir yaklaşım olan doğal ayıklanmacıllk örgütlerin değişim ve hayatta kalmaları konularında yol gösterici niteliktedir. Bu çalışmada, değişim aracı olarak Covid19 süreci ve aşamaları, değişim sonucunda hayatta kalma durumunu açıklamak için de doğal ayıklanmacılık (seçilim) yaklaşımı kullanılmıştır. Dolayısıyla şiddetli bir değişimin yaşandığı bu süreçte örgütsel düzeyde sorunları aşmak ve yol göstermek için evrimsel ve dinamik nitelikte olan doğal ayıklanma yaklaşımı tercih edilmiştir.

Covid-19 süreci kriz ve değişim aşamalarıyla birlikte çevresel baskılar sonucunda örgütleri değişime zorlamıştır. Bu zorunluluk, örgütler açısından her türlü değişimi içeren seçimlere neden olmaktadır. Buna göre Covid-19 sürecinde örgütlerin konumunu doğal ayıklanmacılık yaklaşımı bağlamında öngörmek ve değerlendirmek mümkündür. Covid-19 sürecinin ortaya çıkardığ 1 yeni çevresel koşullar, örgütlerin adaptasyon seçimine neden olduğu bir tepki biçiminde ortaya çıkmaktadır. Bu bakımdan doğal ayıklama bağlamında, örgütlerin yapmış oldukları değişimler çeşitlenme biçiminde ortaya çıkmaktadır. Örgütler doğal ayıklanmanın çeşitlenme ilkesi çerçevesinde, çevresel baskılara tepki göstererek işlevli veya kör çeşitlenme uygularlar. Pandemi sürecinde örgütlerin ortaya çıkan değişimlere daha çok işlevli (amaçlı) bir çeşitlenme ile cevap verdiklerini söylemek mümkündür. Aynı zamanda çevresel baskılardan bağımsız diğer bir ifadeyle kör çeşitlenmenin de yine bu süreçte meydana geldiğini söyleyebiliriz. Dolayısıyla örgütlerin 
pandemi sürecinde çevresel baskıların direttiği değişimlere çeşitlenerek özellikle işlevli (amaçlı) olarak tepki vermeleri gerektiğini söylemek mümkündür.

Örgütler, pandemi sürecinde kriz ve değişim aşamalarının ürettiği yeni koşullara reaksiyon göstererek çeşitlenme yoluna giderler. Ancak çeşitlenme konusunda örgütler, reaksiyon gösterme ve başarı elde etme noktasında farklı dereceler elde etmektedirler. Söz konusu derecelere göre doğal ayıklanmacılık yaklaşımının ikinci ilkesi olan doğal ayıklanma çerçevesinde, örgütlerin bir kısmı başarılı olup yaşamlarını sürdürürken diğerleri ise ayıklanıp yok olurlar. Özellikle pandemi sürecine bağlı olarak bazı örgütler çeşitlenmek için faaliyet gösterdiği çevreden kaynak tedarik etme konusunda rakiplerine göre daha başarılıdır. Bu tip örgütlerin çeşitlenmeleri hem kendi yapıları hem de içinde bulunduğu endüstrideki diğer örgütlerin çeşitlenmeleri konusunda olumlu bir etki yaratır. Böylece bu tip örgütler covid-19 sürecinde başarılı olup yaşamlarını sürdürmektedirler. Buna karş1lık bazı örgütler ise pandemi sürecindeki yeni çevresel koşullara tepki vermek amacıyla çeşitlenme yoluna gitmelerine rağmen bu çeşitlenmeler yararsız veya zararlı olmaktadır. Bu durumun ortaya çıkmasının nedeni söz konusu örgütlerin yeni koşullar özelinde içinde bulundukları çevrede daha az kaynağa sahip olabilmesidir. Dolayısıyla bu tür örgütler ayıklanıp yok olurlar.

Covid-19 sürecinde örgütlerin çeşitlenme yoluna giderek tepki vermeleri, tutunma ve yayılma ilkesi ile geleceğe yönelik örgütlerin yaşamlarını sürdürmelerini sağlamaktadır. $\mathrm{Bu}$ bağlamda tutunma ve yayılma başarılı olan ve yaşamını sürdürebilen örgütlerin yapılarında görülmektedir. Dolayısıyla tutunma ve yayılma ile örgütler geleceğe yönelik olarak yaşamlarını sürdürmelerini sağlayan çeşitlenmelerin devamlılığını ve yayılmasını sağlayabilirler. Bu tip örgütler özellikle pandemi sürecinde faydalı çeşitlenmeler gösterdiklerinde bu durumu tutunma ve yayılma yolu ile geleceğe taşıyabilirler. Son olarak doğal ayıklanma yaklaşımının var olma mücadelesi ilkesi, Covid-19 sürecinde ortaya çıkan yeni zorunlu koşulsal durumların örgütler üzerindeki etki düzeylerine göre söz konusu örgütlerin hayatta kalmalarını belirlemektedir. Aslında pandemi sürecindeki yeni çevresel koşullar değişimle birlikte örgütlerin yaşamlarını sürdürme yeteneğini sorgulamaktadır. Bu noktada örgütlerin varoluş mücadelesi, doğal ayıklanma ilkelerinin tamamıyla birlikte şekillenmektedir. Dolayısıyla varoluş mücadelesi ilkesi, çevresel baskıların yoğun olduğu bu süreçte örgütlerin iş yapma pratikleri, çevresel kaynakların temini ve sağlıklı bir örgüt yapısının oluşturulması bakımından yol gösterici niteliktedir.

Covid-19 sürecinde kriz ve değişim aşamalarının ortaya çıkardığı yeni gerçeklikler ve sürecin baskıladığ koşullar sonucunda örgüt formu değişmeye başlamıştır. Bu bağlamda örgütlerin maruz kaldıkları değiş̧im türünü ve bunun sonucunda doğal ayıklanma süreçleri sonucundaki ileriye dönük konumlarını öngörmek mümkündür. Buna göre Covid-19 sürecinde örgütlerin; plansız, makro, ani, zamana yayılmış, proaktif ve reaktif, aktif ve pasif ile devrim niteliğinde değişim gösterdiklerini söyleyebiliriz. Bu değişimlerin sonucunda örgütlerin doğal ayıklanmacılık yaklaşımı bağlamında yaşamsal durumları sonuçlanır. Örgütler, söz konusu değişim türlerini gerçekleştirdikleri takdirde doğal ayıklanmacılık yaklaşımına göre çeşitlenir, tutunur ve yayılır, var olma mücadelesini kazanır ya da değişime uyum sağlayamaz, zararlı veya faydasız çeşitlenir ya da kaynak teminini sağlayamamasından dolayı ayıklanıp yaşam mücadelesini kaybeder ve yok olur.

\section{Kaynakça}

Açıkgöz, Ö. \& Günay, A. (2020). The early impact of the Covid-19 pandemic on the global and Turkish economy. Turkish Journal of Medical Sciences, 50, 520-526. doi:10.3906/sag-20046

Akdoğan, A. \& Cingöz, A. (2009). "Kurumsal itibar ve kriz yönetimi: Kurumsal itibarı korumada kriz iletişiminin rolü”. Kriz yönetimi, Ed. Haluk Sumer \& Helmut Pernsteiner, İstanbul Bilgi Üniversitesi Yayınları. 
Aldrich, H. E. (1979). Organizations and environments. Englewood Cliffs, Prentice-Hall.

Aldrich, H. E. \& Pfeffer, J. (1976). Environment of organizations. Annual Review of Sociology, 2(1), 79-105. http://dx.doi.org/10.1146/annurev.so.02.080176.000455

Aycan, Z., Kanungo, R.N. \& Mendonça, M. (2016). Kültürler arası bağlamda örgütler ve yönetim. İstanbul: Koç Üniversitesi Yayınları.

Aydın Göktepe, E. (2020). Kriz döneminde iş sürdürülebilirliğine yönelik yönetim uygulamaları; Covid-19 pandemi araştırması. Journal of Social, Humanities and Administrative Sciences, 6(26), 630-638. http://dx.doi.org/10.31589/JOSHAS.311

Barman, A. (2020). Post Cocid-19 businesses and humanity. 1-5, https://www.researchgate.net/publication/340442891

Basım, N. H., Şeşen, H. \& Çetin, F. (2009). "Değişim ve örgütler”. Örgütlerde değişim ve öğrenme, Ed. A. Kadir Varoğlu \& H. Nejat Basım, Siyasal Kitabevi.

Bingül Ak, B., Türk, A. \& Ak, R. (2020). Covid-19 bağlamında tarihteki büyük salgınlar ve ekonomik sonuçları. Turkish $\quad$ Studies, $\quad 15(4), \quad$ 189-200. https://dx.doi.org/10.7827/TurkishStudies.44242

Bostan, S., Erdem, R., Öztürk, Y. E., Kılıç, T., \& Yılmaz, A. (2020). The effect of Covid-19 pandemic on the Turkish society. Electronic Journal of General Medicine, 17(6), 1-8. https://doi.org/10.29333/ejgm/7944

Burgelman, R. A. (1991). Intraorganizational ecology of strategy making and organizational adaptation: Theory and field research. Organization Science, 2(3), 239-262.

Campbell, D. T. (1965). "Variation and selective retention in sociocultural systems". Social change in developing areas: A reinterpretation of evolutionary theory, Ed. Herbert R. Barringer, George Irving Blanksten \& Raymond Wright Mack, Schenkman Publishing Company.

Campbell, D. T. (1969). Variation and selective retention in sociocultural evolution. General Systems, 14, 69-85.

Campbell, D. T. (1994). "How individual and face-to-face-group selection undermine firm selection in organizational evolution”. Evolutionary dynamics of organizations, Ed. Joel A. C. Baum \& Jitendra V. Singh, Oxford University Press.

Chen, J. M., Suen, M. W., Lin, M. J. \& Shieh, F. A. (2001). Organizational change and development. Organization Science, 12, 1-13.

Corning, P. A. (1974). "Politics and the evolutionary process". Evolutionary biology, Ed. Theodosius Dobzhansky, Max K. Hecht \& William C. Steere, Springer.

Çağlar, İ. (2015). Bireysel, örgütsel ve toplumsal düzeyde: değişim ve değişim yönetimi. Nobel Akademik Yayıncılık.

Darwin, C. (1859). On the origin of species by means of natural selection. London: Murry (A Facsimile of the First Edition with an Introduction by Ernst Mayr, Harvard University Press, 1964)

D’Ortenzio, C. (2012). Understanding change and change management processes: A case study. Doctor of Philosophy Thesis at The University of Canberra.

Güven, H. (2020). Covid-19 pandemik krizi sürecinde e-ticarette meydana gelen değişimler. Avrasya Sosyal ve Ekonomi Araştırmaları Dergisi (ASEAD), 7(5), 251-268. 
Hanioğlu, M. Ş. (2020). "Covid-19 sonrası küresel düzen: İki seçenek”. Covid-19 sonrası küresel sistem: Eski sorunlar yeni trendler, Ed. Ufuk Ulutaş, Türkiye Cumhuriyeti Dışişleri Bakanlığı Stratejik Araştırmalar Merkezi.

İlhan, A. (2018). “Örgütsel değişim ve yönetimi”. Örgütsel davranış odakl yönetsel yaklaşımlar, Ed. Enver Aydoğan, Gazi Kitabevi.

ILO (2020). International Labour Organization, https://www.ilo.org/wcmsp5/groups/public/--europe/---ro-geneva/---ilo-ankara/documents/briefingnote/wcms_740193.pdf, Erişim tarihi 04.06.2020

Jones, G. (2017). Örgüt kuramı, örgüt tasarımı ve örgütsel değişim. Çev. Asena Altın Gülova, Lale Oral Ataç \& Deniz Dirik, Gazi Kitabevi.

Kardaş, T. (2020). "Covid-19 pandemisini yeniden düşünmek". Covid-19 sonrası küresel sistem: Eski sorunlar yeni trendler. Ed. Ufuk Ulutaş, Ankara: Türkiye Cumhuriyeti Dişişleri Bakanlığ 1 Stratejik Araştırmalar Merkezi.

Koçel, T. (2018). İşletme yöneticiliği, Beta Yayınları.

KPMG (2020). Understanding the impact of covid-19. https://assets.kpmg/content/dam/kpmg/ch/pdf/impact-of-covid-19.pdf, Erişim Tarihi 02.06 .2020

Lewontin, R. C. (1978). Adaptation. Scientific American, 239(3), 212-230.

Little, A. D. (2020). Leading businesses through the Covid-19 crisis. Arthur D. Little PRISM, Special Report, 1-30.

Mayr, E. (1969). Principles of systematic zoology. McGraw-Hill.

McKelvey, B. (1978). Organizational systematics: Taxonomic lessons from biology. Management science, 24(13), 1428-1440.

McKelvey, B. (1982). Organizational systematics: Taxonomy, evolution, classification. University of California Press.

McKelvey, B. \& Aldrich, H. (1983). Populations, natural selection, and applied organizational science. Administrative Science Quarterly, 28(1), 101-128.

Müftüler Baç, M. (2020). "Küresel salgın tehdidi altında küresel sistem”. Covid-19 sonrası küresel sistem: Eski sorunlar yeni trendler. Ed. Ufuk Ulutaş, Türkiye Cumhuriyeti Dişişleri Bakanlığ Stratejik Araştırmalar Merkezi.

Porter, M. (1980). Competitive strategy. Free Press.

Qiu, W., Rutherford, S., Mao, A., \& Chu, C. (2017). The pandemic and its impacts. Health, Culture and Society, 9, 1-11. https://doi.org/10.5195/hcs.2017.221

Richerson, P. J. \& Boyd, R. (2000). "Evolution: The darwinian theory of social change, an homage to Donald T. Campbell". Paradigms of social change: Modernization, development, transformation, evolution, Ed. Waltraud Schelkle, Wolf-Hagan Krauth, Martin Kohli \& Georg Elwert, Campus Verlag St Martin's Press.

Sargut, S. A. (2017). "Kültür çalışmalarının toplumsal bilimler bağlamındaki epistemolojik konumu". Kültürel bağlamda yönetsel-örgütsel davranış, Ed. Ramazan Erdem \& Cem Şafak Çukur, Türk Psikologlar Derneği Yayınları.

Serinkan, C. \& Arat, G. (2013). Işsletmelerde örgütsel değişim ve iç girişimcilik. Beta Yayınları. 
Suarez, F. \& Oliva, R. (2005). Environmental change and organizational transformation. Industrial and Corporate Change, 14(6), 1017-1041.

Şen, E. \& Bat1, F. (2020). Covid-19 pandemik krizinin yönetim ve ekonomi politik üzerine olas1 etkileri. Yönetim, Ekonomi ve Pazarlama Araştırmaları Dergisi, 4(2), 71-84.

Tahilramani, R. (2011). Enhancing creativity for organizational change. Asian Journal of Management Research, Special Issue 1, 153-162.

Toussaint, E. (2020). Covid-19: Stage assessment on the multidimensional crisis and alternative approaches. https://www.cadtm.org/Covid-19-stage-assessment-on-the-multidimensionalcrisis-and-alternative Erişim Tarihi 05.06.2020

TÜBA (2020). Covid-19 pandemi değerlendirme raporu. Türkiye Bilimler Akademisi Yayınları

Weick, K. E. (1969). The social psychology of organizing. Reading, Addison-Wesley Publishing.

Weick, K. E. (1979). The social psychology of organizing. (2nd ed.) Reading, Addison-Wesley Publishing.

Yavuz, K. (2020). Covid-19 salgınının sosyal politikanın geleceği üzerine etkileri. Akademik Sosyal Araştırmalar Dergisi, 7(45), 181-193.

Zafar, F. \& Naveed, K. (2014). Organizational change and dealing with employees resistance. International Journal of Management Excellence, 2(3), 237-246.

Zarifoğlu, E. (2020). “Covid-19 sonrası küresel ekonomi trendleri”. Covid-19 sonrası küresel sistem: Eski sorunlar yeni trendler. Ed. Ufuk Ulutaş, Türkiye Cumhuriyeti Dişişleri Bakanlığ Stratejik Araştırmalar Merkezi. 